\title{
Effects of Exogenous Ghrelin on Duodenal Growth and Development of African Ostrich Chicks
}

Peng Li ${ }^{1,2 \#}$, Bai-tao $\mathrm{Li}^{1,2 \#}$, Jia-xiang Wang ${ }^{1,2}$, Jing-song $\mathrm{Pi}^{3}$, Ke-mei Peng ${ }^{4}$, Ying Zhang ${ }^{1,2}$

10.18805/IJAR.B-1383

\begin{abstract}
Background: The African ostrich is the largest herbivorous bird in the world, which has high economic value. However, the brooding period of African ostrich is long. During this period, the various organs of the body are not fully developed, the resistance is low and it is easy to get sick, thus affecting the growth and development. Therefore, it is of great significance to enhance the digestion and absorption capacity of ostrich chicks and improve its growth speed in shortening the incubation period of ostrich, improving the survival rate of ostrich and the economic benefits of ostrich breeding.

Methods: Sixteen 40-day-old African ostrich chicks (male or female) were randomly divided into four groups and injected intravenously of Metatarsal vein with saline (control) or ghrelin $(10,50$ and $100 \mu \mathrm{g} / \mathrm{kg}$ ) for 6 days. The morphology, gastrin and pepsin levels in the duodenum were measured using stereology, HE staining and radioimmunoassay.

Result: The 10, 50 and $100 \mu \mathrm{g} / \mathrm{kg}$ of ghrelin administered groups showed lower duodenal length and length index than the control group $(P<0.05)$. Villus length increased in the $50 \mu \mathrm{g} / \mathrm{kg}$ and $100 \mu \mathrm{g} / \mathrm{kg}$ ghrelin administered groups $(P<0.05)$. Crypt depth decreased in the $10 \mu \mathrm{g} / \mathrm{kg}$ ghrelin administered group $(P<0.05)$. The ratio of villus length to crypt depth in each group increased and the difference was significant in the $50 \mu \mathrm{g} / \mathrm{kg}$ and $100 \mu \mathrm{g} / \mathrm{kg}$ ghrelin administered groups $(P<0.05)$. Pepsin content in the duodenum slightly increased in the $10 \mu \mathrm{g} / \mathrm{kg}$ ghrelin administered group $(P>0.05)$ and it significantly decreased in the $50 \mu \mathrm{g} / \mathrm{kg}$ and $100 \mu \mathrm{g} / \mathrm{kg}$ ghrelin administered groups $(P<0.05)$. Gastrin content in the duodenum increased significantly $(P<0.05)$ in the $10 \mu \mathrm{g} / \mathrm{kg}$ ghrelin administered group and decreased in the $100 \mu \mathrm{g} / \mathrm{kg}$ ghrelin administered group $(P<0.05)$.
\end{abstract}

Key words: African ostrich, Development, Duodenum, Ghrelin, Growth.

\section{INTRODUCTION}

Ghrelin is a novel endogenous natural ligand for the growth hormone secretagogue receptor, which is mainly produced by X/A-like cells in the mucosal layer of the gastrointestinal tract (Kojima et al. 1999). A small amount of ghrelin is also produced by other organs (Okuhara et al. 2018). Ghrelin has been found to be widely expressed in other tissues and organs of animals (Chen et al. 2017). A large number of studies have confirmed the inference that the wide distribution of ghrelin immunopositive cells in animals may have many biological roles (Cardona et al. 2012). Ghrelin immunopositive cells are widely distributed in the African ostrich (Wang et al. 2017a; Wang et al. 2017b; Ye et al. 2018; Zhang et al. 2018), Wang et al. (2009) showed that ghrelin immunopositive cells are mainly distributed in the mucosal layer of the gastrointestinal tract of the African ostrich chicks and the number of immunopositive cells gradually decreases from the stomach to the small intestine and then to the large intestine. The number of ghrelin immunopositive cells in the small intestine also showed significant age-related changes, peaked at 90 days and then remained stable. This suggests that ghrelin plays an important physiological role in the digestive system of African ostriches. Previous studies have shown that ghrelin had stimulatory effects on the motility of the antrum and duodenum in both fed and fasted animals (Fujimiya et al. 2011). Moreover, Ghrelin can enhance the autophagy of
${ }^{1}$ College of Animal Science, Yangtze University, Jingzhou 434103, P.R. China.

${ }^{2}$ Ostrich Research Institute, Yangtze University, Jingzhou 434103, P.R. China.

${ }^{3}$ Institute of Animal Husbandry and Veterinary, Hubei Academy of Agricultural Science, Wuhan, 430064, P.R. China.

${ }^{4}$ College of Animal Science and Veterinary Medicine, Huazhong Agricultural University, Wuhan 430070, P.R. China.

\# These authors contributed equally to this work.

Corresponding Author: Jia-Xiang Wang, College of Animal Science, Yangtze University, Jingzhou, 434103, P.R. China.

Email: wangjiaxiang1109@163.com

How to cite this article: Li, P., Li, B.T., Wang, J.X., Pi, J.S., Peng, K.M. and Zhang, Y. (2022). Effects of Exogenous Ghrelin on Duodenal Growth and Development of African Ostrich Chicks. Indian Journal of Animal Research. 56(1): 46-50. DOI: 10.18805/IJAR.B-1383.

Submitted: 13-05-2021 Accepted: 12-08-2021 Online: 11-09-2021

intestinal epithelial cells in rats with sepsis and protect the small intestinal epithelium against sepsis-induced injury (Wan et al. 2016). To our knowledge, the effects of exogenous ghrelin on the duodenal growth and development of African ostrich chicks have not yet been reported. Therefore, in this study, we injected different doses of ghrelin into African ostrich chicks via the metatarsal vein to investigate the effects of the different doses on the length, 
tissue structure and relevant hormones and enzymes of the duodenum of the ostrich chicks and provide a morphological basis for elucidating the effects of ghrelin on the selfrenewal of small intestinal epithelial cells of the chicks. Furthermore, we wanted to provide new ideas for further research on the growth and development of the small intestine of ostrich chicks.

\section{MATERIALS AND METHODS}

\section{Animals}

The present study was conducted at the Ostrich Institute of Yangtze University in Jingzhou, Hubei in the year of 201819. Seven-day-old African ostrich chicks were obtained from the Ostrich Research Institute of Yangtze University, Hubei, China. The birds had free access to water and the feed prepared according to the specifications of the Elsenburg Ostrich feed database (Brand, 2010). After 33 days, the birds were weighed and 16 African ostriches chicks (male or female) with similar weight (average weight: $3.65 \pm 0.53 \mathrm{~kg}$ ) and growth status were selected for the experiment. The experimental procedures and ostrich treatment procedures have been approved by the Animal Protection and Welfare Committee of our institute.

\section{Tissue preparation}

The 16 ostriches chicks were divided into four groups containing four chicks each-one control and three experimental groups. The ostriches chicks were injected intravenously (metatarsal vein) with saline (control) or ghrelin (experimental) at 8 am every day for 6 days; the total injection dose was $500 \mu \mathrm{l}$ per bird. The three experimental groups were treated with $10 \mu \mathrm{g} / \mathrm{kg}, 50 \mu \mathrm{g} / \mathrm{kg}$ and $100 \mu \mathrm{g} / \mathrm{kg}$, respectively, of ostrich ghrelin (synthesized by Shanghai Qiangyao Biological Technology Co., Ltd.) diluted with normal saline. After 6 days of treatment, the birds were weighed and anesthetized with $20 \%$ uratan $(1 \mathrm{~g} / \mathrm{kg}$; China Caoyang No. 2 Middle School Chemical Factory). The abdominal cavity of each bird was opened, The duodenum and its contents were quickly removed, the weight and duodenal length were measured and the length index was calculated. Next, each duodenum is divided into two parts: one part was washed with physiological saline, made into a homogenate and centrifuged (12000 rpm for $10 \mathrm{~min}$ ) at $4^{\circ} \mathrm{C}$ and the supernatant was collected. Then, the contents of pepsin and gastrin were measured by radioimmunoassay. The other part was fixed in $4 \%$ paraformaldehyde solution and then embedded in paraffin; the paraffin blocks were sectioned $(4 \mu \mathrm{m})$ using a Leica microtome (Nussloch Gmbh, Wetzlar, Germany) and the sections were used for hematoxylin and eosin (HE) staining.

\section{Morphometric analysis}

For each intestinal tissue sample, 3 cross-sections were prepared after the samples had been stained with hematoxylin. Further, for each intestinal cross-section, 10 intact, well-oriented crypt-villus units were selected for experiments conducted in triplicate (30 measurements for each sample). Villus height was measured from the tip to the crypt junction and the crypt depth was calculated as the depth of the invagination between and beside villi using a calibrated ocular micrometer. The ratio of villus/crypt length was also calculated. All the measurements were performed under an Olympus light microscope, using the HMIAS-2000 high-definition chromatic color medical science figure analysis program (Qianping, Wuhan, China).

\section{Statistical analysis}

Results are expressed as means \pm standard errors on the mean (means \pm S.E.). Statistical analysis was done using analysis of variance statistics software with Duncan's multiple range test where appropriate. Differences of $\mathrm{P}<0.05$ were considered significant.

\section{RESULTS AND DISCUSSION}

\section{Effects of exogenous ghrelin on the duodenum morphology of African ostrich chicks}

The proximal part of the small intestine, i.e., the duodenum, receives pancreatic juice and bile, which is mixed with partially digested food from the stomach; it plays a vital role in food processing, both physiologically and chemically (Zhang et al. 2020). In the present study, we found that an increase in the body weight of the African ostrich chicks after the injection of $50 \mu \mathrm{g} / \mathrm{kg}$ and $100 \mu \mathrm{g} / \mathrm{kg}$ concentrations of ghrelin ( $P>0.05$; Table 1 ) and the length and length index of the duodenum in the $10 \mu \mathrm{g} / \mathrm{kg}, 50 \mu \mathrm{g} / \mathrm{kg}$ and $100 \mu \mathrm{g} / \mathrm{kg}$ groups were significantly lower than those of the control group ( $\mathrm{P}<0.05$; Table 1 ) and the $100 \mu \mathrm{g} / \mathrm{kg}$ group yielded the lowest result. Slupecka et al. 2012 also found that different doses of ghrelin significantly decreased the length of the duodenum and middle part of the small jejunum. We studied the villus length and crypt depth of the duodenum. The data obtained in this study show that the villus length in the $10 \mu \mathrm{g} / \mathrm{kg}$ group was shorter than that in the control group $(P>0.05)$. The villus length increased significantly in both $50 \mu \mathrm{g} / \mathrm{kg}$ and $100 \mu \mathrm{g} / \mathrm{kg}$ groups $(P<0.05$; Table 2, Fig 1) and the higher the villi and their densities, the larger the surface area for digestion and absorption. (Ohanaka et al. 2018). In addition, we observed that the

Table 1: Effects of exogenous ghrelin on the length of duodenum of African ostrich chicks.

\begin{tabular}{lccc}
\hline $\begin{array}{l}\text { Exogenous } \\
\text { ghrelin }(\mathrm{ug} / \mathrm{kg})\end{array}$ & $\begin{array}{c}\text { Body } \\
\text { weight }(\mathrm{kg})\end{array}$ & $\begin{array}{c}\text { Length } \\
(\mathrm{cm})\end{array}$ & $\begin{array}{c}\text { Length index } \\
(\mathrm{cm} / \mathrm{kg})\end{array}$ \\
\hline 0 & $6.3 \pm 1.51^{\mathrm{a}}$ & $78.6 \pm 4.66^{\mathrm{a}}$ & $12.48 \pm 2.04^{\mathrm{a}}$ \\
10 & $6.1 \pm 2.41^{\mathrm{a}}$ & $59.9 \pm 5.36^{\mathrm{b}}$ & $9.82 \pm 1.87^{\mathrm{b}}$ \\
50 & $6.7 \pm 1.52^{\mathrm{a}}$ & $60.9 \pm 4.66^{\mathrm{b}}$ & $9.08 \pm 2.08^{\mathrm{b}}$ \\
100 & $7.1 \pm 1.22^{\mathrm{a}}$ & $48.1 \pm 4.23^{\mathrm{c}}$ & $6.76 \pm 1.35^{\mathrm{c}}$ \\
\hline
\end{tabular}

The data is expressed as mean \pm standard deviation $(n=4) .{ }^{a-c}$ Different letters in the same column indicate significant differences $(P<0.05)$. 
crypt depth was slightly reduced in the $50 \mu \mathrm{g} / \mathrm{kg}$ and 100 $\mu \mathrm{g} / \mathrm{kg}$ groups when compared with the control group $(P>0.05)$; the crypt depth in the $10 \mu \mathrm{g} / \mathrm{kg}$ group was significantly reduced $(P<0.05$; Table 2 , Fig 1$)$. A large number of stem cells in the crypt can differentiate into intestinal villi cells (Xia et al. 2004) and the rate of crypt cell division is revealed by changes in crypt depth that ultimately can influence the process of digestion in the small intestine (Yang et al. 2009). The villus length to crypt depth ratio represents the absorption capacity of the small intestine (Liu et al. 2020); higher the ratio, stronger the absorption and transport capacity of intestinal epithelial cells (Xie et al. 2020). In the current study, we found that, after injection of different concentrations of ghrelin, the ratio of villus length/crypt depth between each dose group increased when compared with the control group; however, it was not significant in the $10 \mu \mathrm{g} / \mathrm{kg}$ group $(P>0.05)$ and the $50 \mu \mathrm{g} / \mathrm{kg}$ and $100 \mu \mathrm{g} / \mathrm{kg}$ groups showed significant differences $(P<0.05$; Table 2, Fig 1). These findings indicate that exogenous ghrelin can promote crypt differentiation in the duodenum and growth of intestinal villi, thereby improving the absorption of nutrients in the duodenum.

\section{Effects of exogenous ghrelin on digestive enzymes in} the duodenum of African ostrich chicks

The chyme of the glandular stomach and muscular stomach of poultry was mainly affected by pepsin and gastric lipase and pepsin was the main enzyme (Zhang et al. 2005). Due to the faster passage of foods through the proventriculus and muscular stomach, the digestive effects of pepsin are not strong and protein is mainly digested in the small intestine (Fan, 2003). In this study, pepsin content was higher in the duodenum of the $10 \mu \mathrm{g} / \mathrm{kg}$ group than in that of the control group, but the difference was not significant $(P>0.05$; Table 3); pepsin content was significantly lower in the 50 $\mu \mathrm{g} / \mathrm{kg}$ and $100 \mu \mathrm{g} / \mathrm{kg}$ groups ( $\mathrm{P}<0.05$; Table 3 ). This showed that a high dose of ghrelin inhibited pepsin secretion in the duodenum, whereas a low dose of ghrelin might promoted pepsin secretion. Gastrin is the main hormone responsible for the stimulation of gastric acid secretion. The main biological activity of gastrin is to promote the secretion of gastric acid and pepsin, promote the growth of

Table 2: Effects of exogenous ghrelin on the histology of duodenum of African ostrich chicks.

\begin{tabular}{lccc}
\hline $\begin{array}{l}\text { Exogenous } \\
\text { ghrelin }(\mathrm{ug} / \mathrm{kg})\end{array}$ & $\begin{array}{c}\text { Villus } \\
\text { height }(\mu \mathrm{m})\end{array}$ & $\begin{array}{c}\text { Crypt depth } \\
(\mu \mathrm{m})\end{array}$ & $\begin{array}{c}\text { Villus height/ } \\
\text { Crypt depth }\end{array}$ \\
\hline 0 & $2730.19 \pm 300.52^{\mathrm{a}}$ & $174.64 \pm 32.51^{\mathrm{a}}$ & $16.18 \pm 1.04^{\mathrm{a}}$ \\
10 & $2428.41 \pm 215.3^{\mathrm{a}}$ & $145.01 \pm 24.98^{\mathrm{b}}$ & $16.78 \pm 1.25^{\mathrm{a}}$ \\
50 & $2941.25 \pm 278.35^{\mathrm{b}}$ & $167.69 \pm 29.56^{\mathrm{a}}$ & $17.73 \pm 1.09^{\mathrm{b}}$ \\
100 & $3491.68 \pm 298.68^{\mathrm{c}}$ & $170.55 \pm 32.13^{\mathrm{a}}$ & $21.01 \pm 2.02^{\mathrm{c}}$ \\
\hline
\end{tabular}

The data is expressed as mean \pm standard deviation $(n=4)$. $^{a-c}$ Different letters in the same column indicate significant differences $(P<0.05)$.

Table 3: Effect of exogenous ghrelin on pepsin content in duodenum of African ostrich chicks.

\begin{tabular}{lc}
\hline Exogenous ghrelin (ug/kg) & Pepsin content $(\mathrm{U} / \mathrm{ml})$ \\
\hline 0 & $5.1 \pm 0.2^{\mathrm{a}}$ \\
10 & $5.3 \pm 0.2^{\mathrm{a}}$ \\
50 & $4.4 \pm 0.2^{\mathrm{b}}$ \\
100 & $4.3 \pm 0.1^{\mathrm{b}}$ \\
\hline
\end{tabular}

The data is expressed as mean \pm standard deviation $(n=4)$. $^{a-b}$ Different letters in the same column indicate significant differences $(P<0.05)$.

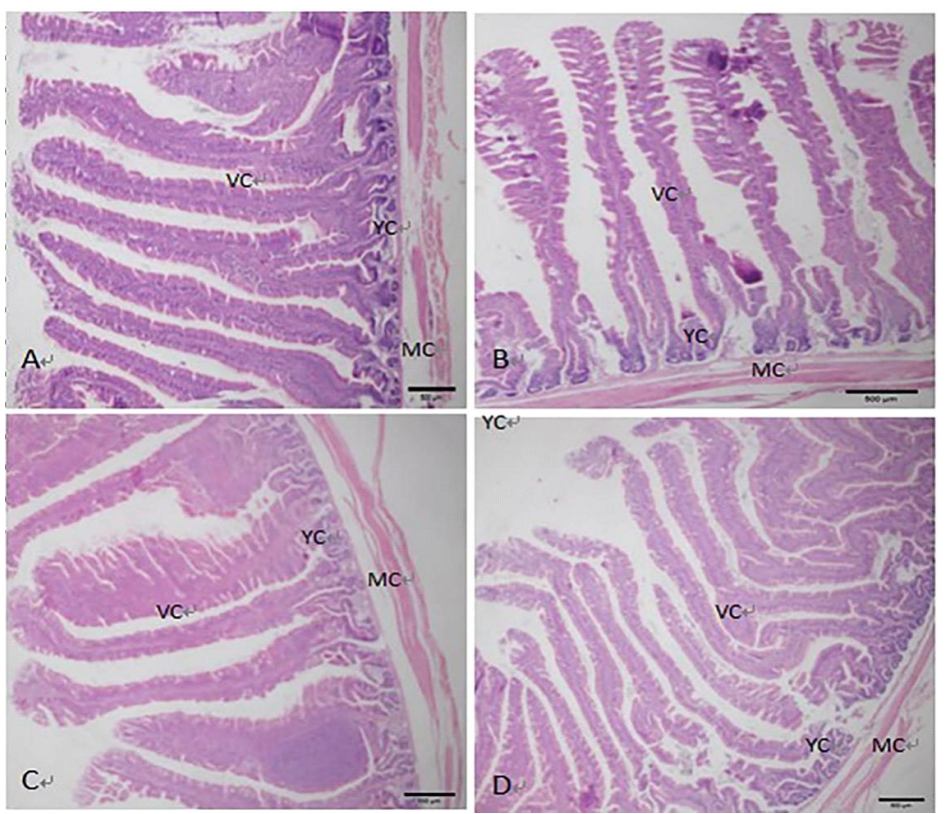

Fig 1: Microstructure of the duodenum of African ostrich chicks with different doses of ghrelin (HE staining).

(A) $0 \mu \mathrm{g} / \mathrm{kg}$ dose group (control group). (B) $10 \mu \mathrm{g} / \mathrm{kg}$ dose group. (C) $50 \mu \mathrm{g} / \mathrm{kg}$ dose group. (D) $100 \mu \mathrm{g} / \mathrm{kg}$ dose group. VC, villi; YC, Crypt; MC, Muscularis. Scale bar: $500 \mu \mathrm{m}$. 
Effects of Exogenous Ghrelin on Duodenal Growth and Development of African Ostrich Chicks

Table 4: Effect of exogenous ghrelin on gastrin content in duodenum of African ostrich chicks.

\begin{tabular}{lc}
\hline Exogenous ghrelin $(\mathrm{ug} / \mathrm{kg})$ & Gastrin content $(\mathrm{U} / \mathrm{ml})$ \\
\hline 0 & $25.7 \pm 1.8^{\mathrm{a}}$ \\
10 & $78.7 \pm 4.6^{\mathrm{b}}$ \\
50 & $26.3 \pm 2.3^{\mathrm{a}}$ \\
100 & $22.3 \pm 1.5^{\mathrm{c}}$
\end{tabular}

The data is expressed as mean \pm standard deviation $(n=4) .{ }^{a-c}$ Different letters in the same column indicate significant differences $(P<0.05)$.

gastrointestinal mucosa, contract the gastric antrum and pyloric sphincter and delay gastric emptying (Liu et al. 2012). In this study, gastrin content was significantly higher in the $10 \mu \mathrm{g} / \mathrm{kg}$ group than in the control group $(P<0.05$; Table 4). Gastrin content was higher in the $50 \mu \mathrm{g} / \mathrm{kg}$ group than in the control group, but the difference was not significant $(P>0.05$; Table 4$)$. Gastrin content was significantly lower in the $100 \mu \mathrm{g} / \mathrm{kg}$ group than in the control group $(P<0.05$; Table 4). This showed that a low dose of ghrelin promoted gastrin secretion and a high dose of ghrelin inhibited gastrin secretion. The above results show that a low dose of ghrelin may promote the growth of duodenum mucosa in African ostrich chicks and a high dose of ghrelin may inhibit the growth of duodenum mucosa in African ostrich chicks; however, the specific effects and mechanism need to be studied further.

\section{CONCLUSION}

The results of the present study indicated that the development of the duodenum of African ostriches chicks was closely associated with the concentration of ghrelin. The high doses of ghrelin promote duodenal villus growth in African ostrich chicks, but inhibit duodenal length and length index and pepsin and gastrin levels. The low doses of ghrelin inhibit duodenal length and length index, but promote the villus length to crypt depth ratio and gastrin and pepsin levels increased in varying degrees. These data suggest that high doses of ghrelin may inhibit the growth and development of the duodenum of African ostriches chicks, while low doses of ghrelin may promote the growth of the duodenum of ostriches chicks.

\section{ACKNOWLEDGEMENT}

We would like to thank the National Natural Science Foundation Project of China. This study was supported by the National Natural Science Foundation Project of China [grant numbers 31402152, 31672504].

\section{REFERENCES}

Brand, T.S. (2010). Elsenburg Ostrich Feed Databases. Elsenburg, Elsenburg Agricultural Research Centre.

Cardona, S.C., Merkestein, M., Skibicka, K.P., Dickson, S.L. and Adan, R.A. (2012). Role of ghrelin in the pathophysiology of eating disorders. CNS Drugs. 26(4): 281-296.
Chen, Z.J., Wu, X.J., Zhu, C., Zhang, W.N., Liang, R., Yan, S.J., Su, H.X. and Chen, Z. (2017). Distribution of 5hydroxytryptamine, ghrelin or glucagon-like peptide-1 immunopositive cells in the gastrointestinal tract of meihua pig. China Animal Husbandry and Veterinary Medicine. 44(5): 1498-1507. (In Chinese)

Fan, H.P. (2003). A comparative study of the digestive effects of gallinaceous ducks on feed nutrients. Chinese Academy of Agricultural Sciences. 3: 85. (In Chinese)

Fujimiya, M., Ataka, K., Asakawa, A., Chen, C.Y., Kato, I. and Inui, A. (2011). Ghrelin, desacyl ghrelin and obestatin on the gastrointestinal motility. Peptides. 32(11): 2348-2351.

Kojima, M., Hosoda, H., Date, Y., Nakazato, M., Matsuo, H. and Kangawa, K. (1999). Ghrelin is a growth-releasing acylated peptide from stomach. Nature. 402(6762): 656-660.

Liu, W.A., Liu, M., He, Y.M., Lv, Y, Guan, C. and Chang, X.R. (2012). Development of brain intestinal peptide for functional gastrointestinal disorders. Journal of Emergency in Traditional Chinese Medicine. 21(6): 951-953. (In Chinese)

Liu, X., Zhang, B., Liu, H., Zhang, G., Zhao, J., Liu, L., Piao, X.S., Song, H., Zhang, S. and Li, Y. (2020). Determination of the available energy values and amino acid digestibility of flammulina velutipes stem waste and its effects on carcass trait and meat quality fed to growing-finishing pigs. Journal of Animal Science and Biotechnology. 11 (1): 41. doi: 10.1186/s40104-020-00449.

Ohanaka, A.U.C., Okoro, V.M.O., Etuk, I.F., Unamba-Oparah, I.C. and Okoli, I.C. (2018). Effects of palm kernel shell ash as organic mineral supplement on performance of broiler chicks. Indian Journal of Animal Research. 52(11): 1590-1596.

Okuhara, Y., Kaiya, H., Teraoka, H. and Kitazawa, T. (2018). Structural determination, distribution and physiological actions of ghrelin in the guinea pig. Peptides. 99: 70-81.

Slupecka, M., Woliński, J. and Pierzynowski, S.G. (2012). The effects of enteral ghrelin Administration on the remodeling of the small intestinal mucosa in neonatal piglets. Regulatory Peptides. 174(1-3): 38-45.

Wan, S.X., Shi, B., Lou, X.L., Liu, J.Q., Ma, G.G., Liang, D.Y. and Ma, S. (2016). Ghrelin protects small intestinal epithelium against sepsis-induced injury by enhancing the autophagy of intestinal epithelial cells. Biomedicine Pharmacotherapy. 83: $1315-1320$.

Wang, J.X., Peng, K.M., Liu, H., Song, H., Chen, X. and Liu, M. (2009). Distribution anddevelopmental changes in ghrelinimmunopositive cells in the gastrointestinal tract of African ostrich chicks. Regulatory Peptides. 154(1-3): 97-101.

Wang, J.X., Li, P., Zhang, X.T. and Ye, L.X. (2017a). Distribution and morphology of ghrelin immunopositive cells in the liver of the African ostrich. International Journal of Morphology. 35(4): 1285-1290.

Wang, J.X., Li, P., Zhang, X.T. and Ye, L.X. (2017b). Distribution and developmental changes of ghrelin-immunopositive cells in the pancreas of african ostrich chicks (Struthio camelus). Poultry Science. 96(9): 3445-3451.

Xia, M.S., Hu, C.H. and Xu, Z.R. (2004). Effects of copper-bearing montmorillonite on growth performance, digestive enzyme activities and intestinal microflora and morphology of male broilers. Poultry Science. 83(11): 1868-1875. 
Xie, Y., Wang, C., Zhao, D., Zhou, G. and Li, C. (2020). Processing method altered mouse intestinal morphology and microbial composition by affecting digestion of meat proteins. Frontiers in Microbiology. 11: 511.

Yang, H., Liu, A., Zhang, M., Ibrahim, S.A., Pang, Z., Leng, X. and Ren, F.Z. (2009). Oral administration of live bifidobacterium substrains isolated from centenarians enhances intestinal function in mice. Current Microbiology. 59(4): 439-445.

Ye, L.X., Wang, J.X., Li, P. and Zhang, X.T. (2018). Distribution and morphology of ghrelin immunopositive cells in the testes of the African ostrich. Pakistan Journal of Zoology. 50(1): 29-34.
Zhang, T.Y., Wang, J. and Li, Y.Q. (2005). Changes in digestive parameters of 0 to 49 day old broilers. China Animal Husbandry and Veterinary Medicine. 32(1): 6-10. (In Chinese)

Zhang, X.T., Wang, J.X., Li, P. and Ye, L.X. (2018). Distribution and morphology of ghrelin immunopositive cells in the lung of the African ostrich. Pakistan Journal of Zoology. 50(1): 257-263.

Zhang, Y.N., Wu, P., Romain, J.B., Didier, D.B., Guillaume, D.C., Chen, X.D. and Xiao, J. (2020). How motility can enhance mass transfer and absorption in the duodenum: Taking the structure of the villi into account. Chemical Engineering Science. 213: 115406. 